\title{
Measuring the Education Gap in Primary and Secondary Schooling in Pakistan
}

\author{
NAUShIN MAHMOOD and G. M. ZaHID
}

\section{INTRODUCTION}

The investment in primary and secondary education is a fundamental premise for achieving social and economic development, for increasing labour productivity and for facilitating expansion in higher education. Ensuring that new generations of children receive at least primary education and that substantial proportions continue up to secondary levels of schooling, an accurate monitoring of the educational change becomes essential for assessing past progress and planning the future course of educational development.

This paper is an attempt in this direction to examine the existing differentials and gaps in enrolment, educational retention and capacity utilisation at primary and secondary levels of schooling in Pakistan with special attention given to the impact of educational plans and policies on these trends. The study is based on both enrolment statistics and data on educational institutions during the seventies and mid-eighties. The enrolment statistics permit calculation of enrolment and continuation ratios for measuring the magnitude of non-participation of children in schools, while information on number of schools provides the possibility of assessing the extent of utilisation of educational facilities and measuring the gaps between existing and needed facilities for schools. We have focused on primary and secondary schooling with a view to recognise and address the basic issue concerning the development of school education in Pakistan.

\section{STATE OF PRIMARY AND SECONDARY EDUCATION IN PAKISTAN}

Although achievement of universal primary education has been an important objective of educational plans in Pakistan, its progress and implementation in terms of increasing school enrolment has been of limited success. Even today,

Naushin Mahmood is Senior Research Demographer and G. M. Zahid is Staff Demographer at the Pakistan Institute of Development Economics, Islamabad. 
nearly half of the relevant school-age children do not attend primary schools. Table 1 shows enrolment targets at primary and secondary levels as documented in the Fifth, Sixth, and Seventh plan periods with their respective achieved levels in the last year of the plan.

Table 1

The Targets and Actual Participation Rates (Percentages)

in Primary and Secondary Schools during the Fifth, Sixth and Seventh Five Year Plans, Pakistan

\begin{tabular}{|c|c|c|c|c|}
\hline \multicolumn{2}{|c|}{ Fifth Plan } & \multicolumn{2}{|c|}{ Sixth Plan } & Seventh Plan \\
\hline $\begin{array}{c}\text { Targets } \\
(1978-83)\end{array}$ & $\begin{array}{c}\text { Actual } \\
(1982-83)\end{array}$ & $\begin{array}{c}\text { Targets } \\
(1983-88)\end{array}$ & $\begin{array}{c}\text { Actual } \\
(1987-88)\end{array}$ & $\begin{array}{cc}\text { Targets } & \text { Actual } \\
(1988-92) & (1989-90)\end{array}$ \\
\hline
\end{tabular}

Primary Schools (Grades I-V)

$\begin{array}{lllllll}\text { Total } & 68.0 & 44.4 & 75.0 & 48.6 & 80.6 & 49.3 \\ \text { Boys } & 90.0 & 60.0 & 90.0 & 63.0 & 89.0 & 64.1 \\ \text { Girls } & 45.0 & 30.0 & 60.0 & 33.5 & 70.0 & 33.8\end{array}$

Secondary Schools (Grade VI-X)

\begin{tabular}{lrrrrrr} 
Total & 26.0 & 18.0 & 28.0 & 20.0 & 33.5 & 21.0 \\
Boys & 35.0 & 24.7 & 35.0 & 27.0 & 43.1 & 29.0 \\
Girls & 13.0 & 9.9 & 16.0 & 12.0 & 22.8 & 12.3 \\
\hline
\end{tabular}

Sources: 1. For enrolment targets, see Government of Pakistan (1975-76 to 1984-85, 1978, 1984).

2. The Actual enrolment rates for the last year of each plan have been calculated on the basis of enrolment data taken from the Pakistan Economic Survey of 1990-91 and the population as estimated by applying the intercensal growth rate (1972-81) in the relevant age group.

The figures in Table 1 indicate that at both primary and secondary levels, not only the progress in enrolment has been slow overtime, its implementation has been much below its targets. For example, by the middle year of the Seventh Five Year Plan (1989-90), the achieved level of enrolment in primary schools is nearly half of the planned estimate ( 80.6 vs 49.3 for total children). This means that the efforts to attain the target of 80 percent primary level enrolment by the years 1992 will have to be substantially increased in the coming years. Besides the availability of limited funds in the education sector, the persistently high rate of population growth exerts an extra pressure on the implementation of the targets of universalising primary education. 


\section{(a) Enrolment Ratios}

Enrolment ratios relate the number of students enrolled at a particular level to the number of population in the age group from which the students would normally be expected to come. These ratios however, cannot serve as precise measures because of the difficulty of specifying the appropriate denominator with precision, given that there is always some leeway in the ages from which students at any given level are drawn. ${ }^{1}$ Since we do not have exact information on the number of students at a given level by age, adjustment for such distortions are not possible. We assume that this pattern is uniform across regions and hence, can make inter-regional comparisons.

The figures in Table 2 reveal that changes in school participation rate have shown progressive trends at primary level and a modest improvement at secondary level with persistent gender differentials, particularly in rural regions of Pakistan. At the primary level, except for the urban Punjab, girls' participation in schools is much lesser than boys across all provinces, more so in rural areas. Boys have the highest participation rates in urban Sindh (76 percent in 1984-85) and girls in the urban Punjab (68 percent in 1984-85). It is also noteworthy that in rural Punjab, girls have shown an encouraging progress in school participation (30 percent in 1984-85), while in other rural regions, less than 10 percent of primary school-age girls are enrolled and show no noticeable change overtime. School participation is the lowest in rural Balochistan where only 3 percent of girls aged 5-9 were attending primary schools in 1984-85.

At the secondary level, enrolment rates show an increasing trend only in urban areas for both boys and girls, although gender differentials still persist across all regions and remain the largest in NWFP and Balochistan. In rural areas, school participation at secondary level is stagnant and disappointing where about 16 percent of boys and only 2.5 percent of girls in the 10-14 age group were enrolled in schools in 1984-85. As expected, girls participation in secondary schooling is negligible in rural areas varying between 0.2 percent in Balochistan to 4 percent in Punjab in 1984-85. This may partly be due to dearth or inaccessibility of secondary schools for girls and socio-cultural hindrances in sending teen-age girls to continue education up to secondary levels in rural areas. We may also note that boys' participation in secondary schooling is quite low in rural Sindh and rural Balochistan either because of the limited schooling facilities, or the demand side constraints or the opportunity costs involved (due to labour value of children) in attending schools in those areas.

${ }^{1}$ Enrolment rates are even less satisfactory for examining trends for single year grades since the students are unlikely to come from only one single year age group and the relative error in specifying the denominator is likely to be greater than for broader educational levels. 
Table 2

Enrolment Ratios at Primary (I-V) and Secondary (VI-X)

Levels by Gender and Regions in Urban-Rural Areas

of Pakistan for 1975-76, 1979-80 and 1984-85

\begin{tabular}{|c|c|c|c|c|c|c|c|c|}
\hline \multirow{3}{*}{$\begin{array}{l}\text { Region/ } \\
\text { Year }\end{array}$} & \multicolumn{4}{|c|}{ Primary } & \multicolumn{4}{|c|}{ Secondary } \\
\hline & \multicolumn{2}{|c|}{ Urban } & \multicolumn{2}{|c|}{ Rural } & \multicolumn{2}{|c|}{ Urban } & \multicolumn{2}{|c|}{ Rural } \\
\hline & Boys & Girls & Boys & Girls & Boys & $\overline{\text { Girls }}$ & Boys & Girl \\
\hline \multicolumn{9}{|l|}{ Pakistan } \\
\hline $\begin{array}{l}1975-76 \\
1979-80 \\
1984-85\end{array}$ & $\begin{array}{l}62.2 \\
64.8 \\
67.3\end{array}$ & $\begin{array}{l}58.2 \\
59.1 \\
63.5\end{array}$ & $\begin{array}{l}49.5 \\
50.1 \\
60.0\end{array}$ & $\begin{array}{l}16.7 \\
16.3 \\
21.1\end{array}$ & $\begin{array}{l}52.8 \\
47.9 \\
53.9\end{array}$ & $\begin{array}{l}30.3 \\
29.7 \\
32.0\end{array}$ & $\begin{array}{l}16.8 \\
15.0 \\
16.4\end{array}$ & \\
\hline \multicolumn{9}{|l|}{ Punjab } \\
\hline $\begin{array}{l}1975-76 \\
1979-80 \\
1984-85\end{array}$ & $\begin{array}{l}64.5 \\
59.2 \\
60.6\end{array}$ & $\begin{array}{l}66.8 \\
64.6 \\
68.1\end{array}$ & $\begin{array}{l}54.3 \\
53.2 \\
61.5\end{array}$ & $\begin{array}{l}23.8 \\
23.4 \\
30.2\end{array}$ & $\begin{array}{l}59.5 \\
49.8 \\
55.3\end{array}$ & $\begin{array}{l}31.2 \\
28.9 \\
33.7\end{array}$ & $\begin{array}{l}20.2 \\
17.6 \\
20.8\end{array}$ & \\
\hline
\end{tabular}

\section{Sindh}

$\begin{array}{rrrrrrrrr}1975-76 & 72.6 & 53.1 & 43.6 & 6.7 & 44.8 & 32.8 & 7.1 & 1.3 \\ 1979-80 & 75.4 & 57.1 & 48.2 & 6.9 & 47.0 & 34.2 & 8.2 & 0.5 \\ 1984-85 & 76.0 & 57.8 & 54.8 & 8.9 & 51.4 & 34.6 & 10.9 & 0.7\end{array}$

N.W.F.P.

$\begin{array}{rrrrrrrrr}1975-76 & 57.1 & 28.7 & 45.1 & 7.4 & 44.7 & 18.2 & 19.1 & 0.8 \\ 1979-80 & 62.9 & 34.5 & 49.5 & 9.2 & 43.4 & 19.0 & 17.6 & 0.8 \\ 1984-85 & 71.8 & 42.0 & 65.9 & 11.6 & 40.1 & 16.4 & 17.0 & 1.1\end{array}$

\section{Balochistan}

\begin{tabular}{lllllllll}
$1975-76$ & 46.9 & 29.9 & 31.6 & 4.9 & 34.6 & 10.1 & 4.0 & 0.2 \\
$1979-80$ & 51.8 & 39.7 & 29.3 & 2.8 & 33.6 & 17.2 & 3.5 & 0.2 \\
$1984-85$ & 64.1 & 45.8 & 29.6 & 3.2 & 52.2 & 34.9 & 3.1 & 0.2 \\
\hline
\end{tabular}

Source: 1. The enrolment data were taken from Central Bureau of Education, Ministry of Education and the population figures were estimated by applying the intercensal growth rate of 1972 and 1981 censuses.

\section{(b) Continuation Ratios}

Continuation ratios relate the number of students enrolled in a particular grade in a given year to the number enrolled in a prior grade in the previous year. Even assuming that enrolment data are accurately reported, continuation ratios are likely to be influenced by such factors as number of students repeating or skipping grades or transferring from one area to another. However, the number 
of repeaters or transferring students tend to cancel each other out in the calculation of continuation ratios. Moreover, the proportion of these students is presumably small at school level and we expect that the overall estimates are not likely to be much affected.

Table 3 presents the continuation ratios at the primary and secondary

Table 3

Net Continuation Ratios at Primary (I-V) and Secondary (VI-X)

Levels by Gender and Regions in Urban-Rural Areas of Pakistan for 1975-76, 1979-80 and 1984-85

\begin{tabular}{|c|c|c|c|c|}
\hline \multirow{3}{*}{$\begin{array}{l}\text { Region/ } \\
\text { Year }\end{array}$} & \multicolumn{2}{|c|}{ Primary } & \multicolumn{2}{|c|}{ Secondary } \\
\hline & Urban & Rural & Urban & Rural \\
\hline & $\overline{\text { Girls }}$ & $\overline{\text { Girls }}$ & $\overline{\text { Girls }}$ & Girls \\
\hline
\end{tabular}

\section{Pakistan}

1975-76 to

1979-80

1980-81 to

1984-85

$64.8 \quad 54.0$

$55.3 \quad 29.3$

69.0

61.6

$29.3 \quad 13.0$

62.3

49.7

$42.3 \quad 28.1$

75.6

58.1

$34.6 \quad 18.1$

\section{Punjab}

1975-76 to

1979-80

$1980-81$ to

1984-85

Sindh

1975-76 to

1979-80

$1980-81$ to

1984-85

80.3

43.7

87.5

31.6

67.7

53.7

$22.2 \quad 12.1$

68.0

$47.1 \quad 58.3$

29.0

$64.2 \quad 58.8$

$30.3 \quad 25.2$

N.W.F.P.

$\begin{array}{llllllll}55.0 & 63.7 & 35.2 & 29.1 & 77.5 & 72.5 & 38.1 & 3.4 \\ 51.3 & 52.1 & 35.0 & 39.4 & 78.9 & 59.1 & 34.6 & 7.8\end{array}$

1975-76 to

1979-80 •

$1980-81$ to

1984-85

$\begin{array}{llllllll}50.1 & 38.1 & 35.5 & 20.7 & 71.2 & 66.7 & 40.1 & 18.0 \\ 36.6 & 31.3 & 25.3 & 16.8 & 79.5 & 63.2 & 50.0 & 33.0\end{array}$

\section{Balochistan}

1975-76 to

1979-80

$1980-81$ to

1984-85

$\begin{array}{llll}53.9 & 41.6 & 23.6 & 11.8\end{array}$

64.1

$\begin{array}{lll}89.4 & 17.4 \quad 1.3\end{array}$

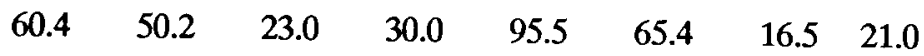

Note: These ratios were estimated on the basis of the enrolment data for each grade over different years. 
levels by gender in urban and rural regions of Pakistan. ${ }^{2}$ It may be noted here that continuation ratios between the end of the primary level and the start of the secondary level cannot be compared to judge the trends in continuing secondary education because the last grade of primary education represents a critical juncture in students educational attainment with substantial proportions terminating their schooling at this point. This is either because many schools, particularly in rural areas, are only primary level schools and thus limit the opportunity for students to continue education. Those who do continue are relatively selective either in terms of being socially and economically better off or have access to secondary level schools.

We can see from Table 3 that the proportions of students continuing through primary grades indicate a mixed and fluctuating pattern by gender and provinces. The salient features notable in the table are that larger proportion of boys than girls continue through the primary grades in both urban and rural areas. In rural areas, except for boys in the Punjab, nearly one-third of students reach the final grade at primary level during the period $1980-81$ to $1984-85$, leaving out between 60 to 70 percent students without the completion of primary education. In urban areas, the proportions continuing upto fifth grade vary across the provinces. The highest ratios are for boys in the Punjab (68 percent in 1984-85) and lowest for girls in the Frontier Province (31 percent in 1984-85). Of the students who enter the secondary school stream (grades VI-X), about 76 percent of boys and 58 percent of girls continued education up to the final grade in urban areas in 1984-85. The situation is not as encouraging in rural areas where continuation ratios become quite low particularly in case of girls. This means that out of the small proportions who start secondary education, a substantial number of students leave schools prior to attaining secondary school certificates. The failure of the schooling system to retain students in schools may be due to several factors among which poverty, high opportunity cost of education, negative attitude towards girls' education and low motivation among parents to educate their children, particularly in rural areas, are some of the most cited reasons for low continuation rates in schools. This suggests that in rural areas, where the continuation of education among children, especially girls is the lowest, there is a need to expand and improve the schooling

${ }^{2}$ The approach to calculate these ratios at the primary level for the years 1975-76 to 1980 and 1980-81 to 1985 is by simply relating enrolments in grade $V$ in $1979-80$ and 1984-85 to the enrolments in grade I five years earlier in 1975-76 and 1980-81, respectively. This would indicate the proportion of students continuing between grades $I$ and $V$ for the two time periods under study. The same approach is used for calculating continuation ratios at secondary level by relating enrolment data, separated by the equivalent number of calendar years, for the particular grades in question (in this case grade VI to $\mathrm{X}$ ). 
network in terms of provision of schooling facilities, quality of teachers, improvement in the relevance of curriculum and efficient use of available resources [Ghafoor (1989).] These are some of the general suggestions cited on the supply side to reform our schooling system but they emphasise the need for studying the specific determinants of schooling in the socio-structural context of Pakistan, and also for identifying the remedial factors related to high drop-out rates at primary level.

\section{(c) School Capacity Utilisation}

If school capacity is viewed as a unit with enrolment capacity of 200 students, it gives an average class size of 40 children, a general standard set by the government in primary schools [Ahmed et al. (1983)]. Table 4 shows student-institution ratios by gender and provinces for primary and secondary levels, respectively for the years 1975-76, 1979-80 and 1984-85. It appears from Table 4 that primary schools are greatly under utilised in rural regions with an average class size of twenty or less students, whereas primary institutions in urban areas appear to be overcrowded, with an average class size of 50 or more students in each grade. The extremely high ratios for Balochistan, particularly in case' of boys, are indicative of limited number of schools in relation to enrolled students. The increase in these ratios in urban areas of NWFP and Balochistan reflects that number of primary schools have not expanded in correspondence with increment in enrolment resulting in overcrowding of schools. This suggests that supply-side constraints are more of a problem in urban areas while low student-institution ratios in rural areas are reflective of a low demand for education with under-utilised primary level institutions.

At secondary level, student-institution ratios show large variations among provinces by gender and urban-rural residence. As Table 4 shows, secondary level institutions are overcrowded in urban areas with an average class size of 70 or more for boys and close to 50 or more for girls, with the exception of NWFP and Balochistan. This suggests for the provision of more secondary level institutions in urban areas. It may be pointed out here that some institutions in urban areas have double shifts or multiple sections of a class to cope with the problem of increasing number of students which may have resulted in high number of students per school. . In rural areas, however, student-institutions ratios at secondary level are quite low, particularly for girls in all provinces. This is clearly reflective of extremely low enrolment of girls in relation to existing institutions and suggests for providing motivations for girls to enter and stay in schools to raise the level of school capacity utilisation. 
Table 4

Student-Institution Ratios at Primary and Secondary Level by Gender and Urban-Rural Regions of Pakistan for 1975-76, 1979-80 and 1984-85

\begin{tabular}{|c|c|c|c|c|c|c|}
\hline \multirow{2}{*}{$\begin{array}{l}\text { Region/ } \\
\text { Year }\end{array}$} & \multicolumn{3}{|c|}{ Urban } & \multicolumn{3}{|c|}{ Rural } \\
\hline & Total & Boys & Girls & Total & Boys & Girls \\
\hline \multicolumn{7}{|c|}{ Primary Level } \\
\hline \multicolumn{7}{|l|}{ Punjab } \\
\hline $\begin{array}{l}1975-76 \\
1979-80 \\
1984-85\end{array}$ & $\begin{array}{l}390.3 \\
327.4 \\
278.6\end{array}$ & $\begin{array}{l}369.1 \\
307.9 \\
238.4\end{array}$ & $\begin{array}{l}415.5 \\
349.3 \\
332.1\end{array}$ & $\begin{array}{l}67.2 \\
65.6 \\
65.4\end{array}$ & $\begin{array}{l}77.3 \\
75.9 \\
69.4\end{array}$ & $\begin{array}{l}50.5 \\
48.9 \\
58.7\end{array}$ \\
\hline \multicolumn{7}{|l|}{ Sindh } \\
\hline $\begin{array}{c}1975-76 \\
1979-80 \\
1984-85\end{array}$ & $\begin{array}{l}255.8 \\
299.7 \\
286.5\end{array}$ & $\begin{array}{l}221.4 \\
244.2 \\
245.8\end{array}$ & $\begin{array}{l}331.3 \\
441.4 \\
372.6\end{array}$ & $\begin{array}{l}45.2 \\
54.8 \\
64.3\end{array}$ & $\begin{array}{l}44.9 \\
54.7 \\
64.6\end{array}$ & $\begin{array}{l}46.9 \\
55.3 \\
62.3\end{array}$ \\
\hline \multicolumn{7}{|l|}{ N.W.F.P } \\
\hline $\begin{array}{l}1975-76 \\
1979-80 \\
1984-85\end{array}$ & $\begin{array}{l}262.0 \\
277.9 \\
298.8\end{array}$ & $\begin{array}{l}298.1 \\
318.0 \\
377.3\end{array}$ & $\begin{array}{l}208.7 \\
223.6 \\
217.4\end{array}$ & $\begin{array}{r}75.2 \\
84.7 \\
107.8\end{array}$ & $\begin{array}{r}83.4 \\
95.8 \\
126.4\end{array}$ & $\begin{array}{l}45.7 \\
50.4 \\
56.6\end{array}$ \\
\hline \multicolumn{7}{|l|}{ Balochistan } \\
\hline $\begin{array}{l}1975-76 \\
1979-80 \\
1984-85\end{array}$ & $\begin{array}{r}549.4 \\
897.4 \\
1382.9\end{array}$ & $\begin{array}{r}819.3 \\
1323.3 \\
2100.1\end{array}$ & $\begin{array}{l}353.1 \\
617.9 \\
912.3\end{array}$ & $\begin{array}{l}38.9 \\
42.5 \\
51.6\end{array}$ & $\begin{array}{l}41.1 \\
46.9 \\
55.3\end{array}$ & $\begin{array}{l}28.6 \\
20.9 \\
31.4\end{array}$ \\
\hline & \multicolumn{6}{|c|}{ Secondary Level } \\
\hline \multicolumn{7}{|l|}{ Punjab } \\
\hline $\begin{array}{l}1975-76 \\
1979-80 \\
1984-85\end{array}$ & $\begin{array}{l}502.1 \\
429.8 \\
496.3\end{array}$ & $\begin{array}{l}618.7 \\
525.9 \\
590.3\end{array}$ & $\begin{array}{l}353.4 \\
316.6 \\
386.0\end{array}$ & $\begin{array}{l}141.4 \\
133.2 \\
140.0\end{array}$ & $\begin{array}{l}171.9 \\
159.1 \\
173.9\end{array}$ & $\begin{array}{l}52.9 \\
56.6 \\
65.2\end{array}$ \\
\hline \multicolumn{7}{|l|}{ Sindh } \\
\hline $\begin{array}{c}1975.76 \\
1979-80 \\
1984-85\end{array}$ & $\begin{array}{l}326.6 \\
383.1 \\
410.9\end{array}$ & $\begin{array}{l}308.4 \\
358.1 \\
368.3\end{array}$ & $\begin{array}{l}359.7 \\
429.5 \\
506.2\end{array}$ & $\begin{array}{r}91.7 \\
111.8 \\
166.9\end{array}$ & $\begin{array}{r}90.4 \\
117.6 \\
176.3\end{array}$ & $\begin{array}{r}103.2 \\
55.4 \\
83.8\end{array}$ \\
\hline \multicolumn{7}{|l|}{ N.W.F.P. } \\
\hline $\begin{array}{l}1975-76 \\
1979-80 \\
1984-85\end{array}$ & $\begin{array}{l}400.9 \\
370.4 \\
307.8\end{array}$ & $\begin{array}{l}514.3 \\
498.8 \\
370.4\end{array}$ & $\begin{array}{l}246.0 \\
221.7 \\
210.4\end{array}$ & $\begin{array}{l}162.2 \\
144.5 \\
135.9\end{array}$ & $\begin{array}{l}179.7 \\
158.8 \\
148.4\end{array}$ & $\begin{array}{r}412.3 \\
40.9 \\
52.1\end{array}$ \\
\hline \multicolumn{7}{|l|}{ Balochistan } \\
\hline $\begin{array}{l}1975-76 \\
1979-80 \\
1984-85\end{array}$ & $\begin{array}{l}167.5 \\
165.8 \\
351.2\end{array}$ & $\begin{array}{l}254.9 \\
205.3 \\
404.8\end{array}$ & $\begin{array}{r}67.9 \\
113.5 \\
282.9\end{array}$ & $\begin{array}{l}33.8 \\
31.3 \\
32.1\end{array}$ & $\begin{array}{l}35.9 \\
32.4 \\
33.8\end{array}$ & $\begin{array}{l}10.9 \\
15.4 \\
14.5\end{array}$ \\
\hline
\end{tabular}




\section{SUMMARY AND CONCLUSIONS}

The present study examines the changes and differentials by gender and urban-rural regions in primary and secondary education in Pakistan. The indicators used to assess educational change during 1975 to 1985 are enrolment and continuation ratios based on enrolment data. In broad terms, we find that changes in school-level enrolment have been more obvious at primary level in urban areas and very modest at secondary level. Young children who entered primary and secondary school are still in a minority in rural areas particularly in case of girls by the mid-eighties. School participation is the lowest in rural Balochistan where only 3 percent of girls aged 5-9 are reported to be attending primary schools in 1984-85, while the corresponding proportion is 30 percent for girls in rural Punjab. The highest participation rates at primary level are found for boys in urban Sindh and for girls in urban Punjab (76 percent and 68 percent, respectively in 1984-85). Among provinces, Punjab is the only region showing encouraging trends in girl enrolment ratios in both urban and rural areas, whereas in other provinces, rural girls lag much behind.

Besides low enrolment, low continuation ratios are also common through primary and secondary grades and pose as a serious problem of educational waste. Our results indicate that smaller proportion of girls than boys continue up to the final grade of a particular level. Regarding school capacity utilisation, our results indicate that students per school are quite high in urban regions and very low in rural areas. This is reflective of overcrowding of urban school and under-utilisation of educational rural institutions in relation to the students enrolled. We inferred from this finding that in urban areas supply of schools and its facilities are of more concern than the demand for education, whereas in rural areas, besides the constraints on accessibility to schools, demand for entering the school system appears to be a serious issue.

We infer from our analysis that slow expansion in enrolments, low continuation ratios, substantial educational waste through high drop-outs, and deficient school facilities, all contribute towards a slow progress in the expansion of educational base and a delay in the achievement of universal primary education. These problems are carried over to secondary level resulting in a much lower absorption of primary school output in secondary education. Our analysis leads us to suggest that for an improvement in prevailing state of school education in the country, it will not only require larger financial allocations to cope with the supply side constraints but also some incentives for attracting school-age children to schools, particularly girls in rural areas and motivating them to continue to achieve a particular level of education. In rural areas, where a substantial proportion of poor and other 
disadvantaged social groups of population live with little motivation and access to join the schooling system, there is a need to establish an efficient and attractive school system and incentives to increase participation in schools.

\section{REFERENCES}

Ahmed Salehuddin et al. (1983) Primary Education Network in Bangladesh. National Foundation for Research on Human Resources Development. Central Bureau of Education (1975-85) Ministry of Education, Islamabad. Ghafoor Abdul (1990) Primary Education of the Girl Child in Pakistan. Islamabad: Academy of Educational Planning and Management.

Pakistan, Government of (Various Issues) Annual Plans. Islamabad: Planning Commission.

Pakistan, Government of (1978) The Sixth Five Year Plan: 1983-88. Islamabad: Planning Commission.

Pakistan, Government of (1984) Census Report of Pakistan, Punjab, Sind, NWFP and Balochistan Provinces, 1981. Islamabad: Population Census Organization.

Pakistan, Government of (1988) The Seventh Five Year Plan: 1988-92. Islamabad: Planning Commission.

Pakistan, Government of (1990-91) Pakistan Economic Survey. Islamabad: Economic Adviser's Wing. Finance Division. 


\section{Comments on \\ "Measuring the Education Gap in Primary and \\ Secondary Schooling in Pakistan"}

The Pakistan Institute of Development Economics (PIDE) and its management deserves complements for holding the Eighth Annual General Meeting of the Pakistan Society of Development Economists. The Institute has been instrumental in encouraging and motivating young economists to undertake research on various aspects of Pakistani society including the development of education in the country. The paper contributed by Naushin Mahmood and G. M. Zahid is an excellent attempt to re-establish the facts regarding the status of primary and secondary education in the country.

On basis of the existing literature, the authors have stated that we are faced with large disparities and imbalances in our educational structure. They have stated that: "concentration of public spending on higher rather than primary and secondary education may partly be accounted for a slow expansion in primary level enrolments and inequalities in our education system." They have further stated that "there has been an increased emphasis on primary education in recent years and suggests that a reallocation of public funds from higher to primary education would improve the efficiency and equity considerations of the present education system." The authors have admitted that their study is based on both enrolment statistics and data on educational institutions during the Seventies and mid-Eighties.

The authors have discussed the structure and organisation of primary and secondary education; highlighted the targets of participation rates at primary and secondary level and achievement of the targets during the Fifth, Sixth, and Seventh Plan periods (1978-1990). They have presented their findings of enrolment ratios, continuation ratios, educational attainment indicators by province and gender. School capacity utilisation by rural and urban areas as well as gender have also been presented in the paper. The data in Table 7 reveals that "primary schools are greatly under-utilised in rural regions with an average class size of twenty or less students."

The authors have concluded that "we infer from our analysis that slow expansion in enrolments, low continuation ratios, substantial educational waste through high dropouts, limited financial allocations and deficient school facilities, all contribute towards a slow progress in the expansion of the educational base and a delay in the achievement of universal primary education." The following comments are offered for further improvement of the paper:

The title of the paper seems to give the impression that the gap between 
the primary and secondary education in terms of facilities and opportunities has been discussed. In fact, the authors have taken a comprehensive view of the situation by differentiating between primary and secondary education in terms of participation; continuation or retention; and utilisation of the existing facilities. The authors may like to reconsider the title. Suggested titles could be "Development of Primary and Secondary Education in Pakistan"; "Status of Primary and Secondary Education in Pakistan".

The authors have presented their findings based on data of the Seventies and mid-Eighties in a tabular form. Each table is followed by an analytical discussion which adds to the strength and reliability of the paper. Had the authors collected the latest data from the Central Bureau of Education and based their analyses on updated data, it would have further lent strength to their existing findings/analyses.

The authors have stated that the concentration of public spending have been on higher rather than primary and secondary education. They have suggested that a reallocation of public funds from higher to primary education would improve efficiency and equity considerations. Admitted that the proportion of public spending had been higher in college and university education, yet the state of higher education does not seem to be better. The physical facilities like libraries, laboratories, etc. are still lacking in institutions of higher learning. They are not well staffed and equipped which further deteriorates the quality of higher education and which is supposed to produce the human capital needed for instructional purposes in the primary and secondary institutions. Thus, a proper balance has to be maintained between and among various sub-sectors of education.

The participation rates of females at the primary and secondary levels, especially in the rural areas have remained constantly low despite persistent efforts of the Government. The authors have not been able to come forward with any concrete suggestions or recommendations which may help in resolving such a serious problem. While discussing continuation ratios, it has been suggested that in rural areas there is need to expand and improve the school network in terms of schooling facilities, quality of teachers, etc. but elsewhere it has been concluded that school facilities in rural areas are highly underutilised. There is inherent contradiction in findings and recommendations of the authors. In Table 4, the 3rd figure in col. 1 appears to be totally misleading which needs to be checked up.

Abdul Ghafoor

National Educational Council,

Islamabad. 